\title{
THE ROLE OF BONDING AND BRIDGING COGNITIVE SOCIAL CAPITAL IN SHAPING ENTREPRENEURIAL INTENTION IN TRANSITION ECONOMIES
}

\author{
Ksenija Vuković* \\ Irena Kedmenec ${ }^{* *}$ \\ Kiril Postolov ${ }^{* * *}$ \\ Kiril Jovanovski*** \\ Dina Korent ${ }^{* * * * *}$
}

Received: 29. 4. 2015

Original scientific paper

Accepted: 31.5 .2017

\author{
UDC 330.32-053.6>(497.5+497.7)
}

Entrepreneurship is an important factor of potential growth and development that will determine the development dynamics of transition countries in the future. Starting from the theory of planned behaviour and the social cognition theory, the paper argues that bonding and bridging cognitive social capital may positively influence entrepreneurial intentions of young people in Croatia and Macedonia. The hypotheses were tested by using structural equation modelling. Our findings indicate that bridging and bonding social capital could be significant enhancers of entrepreneurial intention. The fact that those individuals who have poor bonding social capital may get their chance through bridging social capital seems as a good indicator. Bridging social capital that forms in an entrepreneurial environment can

Ksenija Vuković, Department of Economics, Faculty of Organization and Informatics, University of Zagreb, Pavlinska 2, 42000 Varaždin, Croatia, Phone +385 42390 835, Email: ksenija.vukovic@foi.hr

** Irena Kedmenec, Department of Economics, Faculty of Organization and Informatics, University of Zagreb, Pavlinska 2, 42000 Varaždin, Croatia, Phone +385 42390 835, E-mail: irena.kedmenec@foi.hr

*** Kiril Postolov, Department of Management, Faculty of Economics, Ss. Cyril and Methodius University of Skopje, Blvd. Goce Delchev 9V, 1000 Skopje, FYR Macedonia, Phone + 389 232868 38, E-mail: kirilp@eccf.ukim.edu.mk

**** Kiril Jovanovski, Department of Financial Management, Faculty of Economics, Ss. Cyril and Methodius University of Skopje, Blvd. Goce Delchev 9V, 1000 Skopje, Macedonia, Phone +389232868 86, E-mail kirilj@eccf.ukim.edu.mk

***** Dina Korent, Department of Economics, Faculty of Organization and Informatics, University of Zagreb, Pavlinska 2, 42000 Varaždin, Croatia, Phone +385 42390 835, E-mail: dina.korent@foi.hr 
Management, Vol. 22, 2017, 1, pp. 1-33

$\mathrm{K}$. Vuković et al: The role of bonding and bridging cognitive social capital in shaping...

encourage young people in their self-employment efforts. Furthermore, our research implies several possible measures of enhancing the efficiency of entrepreneurial education.

Keywords: Entrepreneurial intention, Cognitive social capital, Theory of planned behaviour, Republic of Croatia, FYR of Macedonia

\section{INTRODUCTION}

When considering the development possibilities of different countries and regions, entrepreneurship stands out as an important factor of the potential growth and development (Audretsch 2007, Carree and Thurik 2010). The existing differences in economic and entrepreneurial indicators between developed and less developed countries encourage rethinking of the path that the countries with lacking entrepreneurial capacity should take in order to ensure long-term economic and social prosperity. In a way, transition countries represent a kind of laboratory for economic research and a thankful material for making various comparisons with developed countries (i.e., the Western countries), as well as comparisons among transition countries themselves, which differ in their economic development, history and culture.

According to Peng and Shekshnia (2001), future differences among transition countries will be based on entrepreneurial activity and education. A career choice, according to social cognition theory, represents a cognitive process driven by beliefs, attitudes and experiences which is mainly influenced by such factors as an individual's personal background and experiential knowledge (Lent et al., 1994). Thus, when trying to increase entrepreneurial activity in an economy, the focus has to be on strengthening its predictors. Since entrepreneurial activity is in the domain of planned behaviour, its best predictor is entrepreneurial intention.

Despite the fact that the model based on the Ajzen's theory of planned behaviour (Ajzen 1988) provides a coherent and robust theoretical framework allowing for the generalization that enables understanding and prediction of entrepreneurial intention, researchers found that isolated modelling of only individual or contextual factors does not yield satisfactory explanatory power and validity for the prediction of behaviour (Krueger et al. 2000). Therefore, the main objective of this study is to investigate the possible influence of the immediate and broader environment on students' entrepreneurial intentions by introducing cognitive social capital within concerned entrepreneurial intention model. 
The cognitive form of social capital (Nahapiet and Ghoshal 1998) is a result of mental processes and ideas empowered by culture and ideology which generate values, attitudes and beliefs. During the process of attitude formation people are exposed to various influences of their culture, parents, groups and individual personality traits (Kretch and Crutcfield 1964). Woolcock (2004) differentiates between bonding (connecting closer actors) and bridging (connecting distant actors) social capital. Thereby, bonding social capital stems from strong intracommunity ties and the bridging social capital stems from weak inter-community ties and they are both potentially important in the process of shaping one's entrepreneurial intention (Linan and Santos 2007).

The main research question of the paper is the following: what is the importance of bonding and bridging cognitive social capital in shaping entrepreneurial intention in the context of transition economies. Although the prediction of entrepreneurial intentions of students has been the object of interest for many researchers, their studies have mainly focused on developed European countries (Kolvereid 1996, Autio et al. 2001; Linan and Chen 2009) and the USA (Krueger et al. 2000, Depillis and Reardon 2007). Outside this circle, entrepreneurial intentions of students were the subject of research in a very small number of countries, such as Russia (Tkackev and Kolvereid 1999), South Africa (Gird and Bagraim 2008), India and Iran (Moriano et al. 2012). Studies of students' entrepreneurship skills and psychosocial predispositions to succeed were performed in Baltic and Central European transition countries (Bernat et al. 2009, Pawlowska et al. 2010). Therefore, the primary contribution of this article is the study of entrepreneurial intention formation in the specific conditions of South-eastern Europe.

Considering the available results of previous studies of social capital in Macedonia and Croatia that mostly refer to an institutional approach to social capital and in which the key actors are the private and public sector with the focus on civil and political freedoms, transparency and accountability (Štulhofer and Landripet 2004, Štulhofer 2004, Mihaylova 2004, Bežovan et al. 2005, Daut 2006), the second contribution that this article has to offer is the analysis of the impact of individual bonding and bridging social capital on configuration of entrepreneurial intentions of Croatian and Macedonian students.

\section{ENTREPRENEURIAL INTENTION AND SOCIAL CAPITAL}

The main focus of this research is the potential impact of different types of social capital on entrepreneurial intention. The possible ways in which this impact may occur are explained below and tested in the following chapter. 


\subsection{Entrepreneurial intention model}

Intention is a conscious state of mind that directs attention towards a specific object or pathway to achieve it (Bird 1989). Thus, entrepreneurial intention is a conscious state of mind that directs attention towards being an entrepreneur or towards means that are necessary to become one. The research of entrepreneurial intention mainly uses two starting points. One starting point is the model of entrepreneurial event (Shapero and Sokol 1982) and the second is the theory of planned behaviour (Ajzen 1988). They are both widely accepted in predicting entrepreneurial intentions.

In the model of entrepreneurial event (Shapero and Sokol 1982), the emphasis lies on the conditionality of entrepreneurial events, based on desirability perception (one's personal value system and the system of social values to which one belongs) and feasibility (financial support and potential partners). The theory of planned behaviour, based on the theory of reasoned action (Ajzen and Fishbein 1980), introduces an essential element that the individual needs in order to demonstrate a particular behaviour, and that is the element of perceived control over the behaviour and behavioural outcomes. It was observed that there was an overlap in these two approaches. Their complementarity resulted in the creation of an acceptable construct which examines the intention of entrepreneurial behaviour among potential entrepreneurs.

The ability to understand and predict intentions has intrigued the researchers whose research focuses on managers and entrepreneurs (Tubbs and Ekeberg 1991). Intention has been shown to be the best predictor of behaviour, especially in those situations where the observation of behaviour is difficult or involves unpredictable time lags (Krueger and Brazeal 1994). The creation of new entrepreneurial ventures is a good example of such behaviour. Starting a business venture is not the result of mere coincidence, but falls into the category of planned behaviour (Autio et al. 2001).

The theory of planned behaviour (Ajzen 1988, 1991) lists these three predictors of intention: the attitude towards the behaviour, the subjective norm and the perceived behavioural control (indirect predictors of behaviour).

Attitude towards the behaviour refers to the attractiveness of the behaviour. In the context of entrepreneurial intention (i.e., a decision to start a business) the attitude is based on the degree of personal evaluation of the entrepreneurial 
profession and whether it is positively or negatively formulated (Ajzen 1991, 2001, Kolvereid 1996).

Subjective norm refers to the perception of social pressure to perform an entrepreneurial behaviour, such as launching an entrepreneurial venture (Ajzen 1991). In studies of entrepreneurial intention, social norms proved to be a weaker predictor of behavioural intention (Krueger et al. 2000, Autio et al. 2001). In the study conducted by Moriano et al. (2012), social norms were significantly predictive for the population of students in the Netherlands and India, as well as in the research among the population of students in Russia (Tkachev and Kolvereid 1999). If not directly, the influence of subjective norms exists indirectly through their impact on attitudes and perceived behavioural control (Linan et al. 2011).

With the introduction of a component named perceived behavioural control, the theory of reasoned action (Ajzen and Fishbein 1980) has been modified into the theory of planned behaviour. Previously, intentions were not seen as subjected to a person's feelings on whether they can control a certain behaviour. Thus, this variable presents an improvement because it includes a motivational impact on one's behaviour, which is not under voluntary control (Ajzen 1991, 2002). According to the model of entrepreneurial event (Shapero and Sokol 1982), this component should be an indicator of feasibility perceptions among potential entrepreneurs when it comes to launching entrepreneurial ventures. This variable is similar to self-efficacy (Bandura 1997) but, unlike self-efficacy, the perceived behavioural control includes current behavioural control and the perception of future behavioural control (expectations).

On a sample of secondary school students, Paco et al. (2011) found the positive impact of attitudes towards entrepreneurship on perceived behavioural control. This means that increasing the desirability of a behaviour also increases the perceived feasibility, which then produces an even greater total effect of desirability on intention. Based on the theoretical foundations and empirical research on the prediction of entrepreneurial intention, the first group of hypotheses will be tested:

\section{Hla:Attitude towards entrepreneurship has a positive impact on entrepreneurial} intention.

H1b:Subjective norm has a positive impact on entrepreneurial intention.

Hlc:Perceived behavioural control has a positive impact on entrepreneurial intention. 
Management, Vol. 22, 2017, 1, pp. 1-33

$\mathrm{K}$. Vuković et al: The role of bonding and bridging cognitive social capital in shaping...

H1d:Subjective norm has a positive impact on the attitude towards
entrepreneurship.

Hle: Subjective norm has a positive impact on the perceived behavioural control.

H1f: Attitude towards entrepreneurship has a positive impact on the perceived behavioural control.

\subsection{The impact of cognitive social capital on entrepreneurial intention}

Since entrepreneurship is not only an economic but also a social phenomenon, the social aspect of entrepreneurship often appears in literature, mostly through topics such as social capital and social networking. Social capital is a unique concept with different definitions of a large number of authors. Despite the pluralism of theories, definitions and paradigms, there are three common aspects in defining social capital: social actors, resources and relationships among actors (Ignjatović and Tomanović, 2011). The three most cited authors are Bourdieu, Coleman and Putnam (Ignjatović and Tomanović, 2011). Bourdieu (1986) distinguishes between different kinds of capital (economic, cultural, social and symbolic) that can be converted, whereby economic capital is the basis for reproducing social inequality. Coleman (1988) points out the "closure" argument - social capital is created among strongly interconnected elements. Putnam (2001) emphasizes the importance of all forms of association that can bridge and connect social actors.

In a group of authors that link social capital with economic growth and development, Fukuyama and Woolcock stand out. Fukuyama (2001) places an emphasis on the cultural community and economic development. Woolcock (2004) differentiates between bonding (connecting closer actors), bridging (connecting distant actors) and linking capital (relationship between actors and institutions). Burt and Granovetter are distinguished among the authors who interpret the social capital by the theory of networks. Granovetter $(1973,1985)$ differentiates between the strong ties, which develop between family members or ethnic groups, and the weak ties, which represent one's contacts with networks and organizations outside their close community. Thereby, bonding social capital stems from strong intra-community ties and the bridging social capital stems from weak inter-community ties (Linan and Santos 2007). Burt presents the argument of structural gaps that allow the connection of distant actors of the social structure. Burt (2001) concludes the debate on two arguments about network structures that create social capital - Coleman's closure argument and Burt's structural hole argument, suggesting a more general network model of social capital. According to Burt (2001:31): "brokerage across structural holes is the 
Management, Vol. 22, 2017, 1, pp. 1-33

K. Vuković et al.: The role of bonding and bridging cognitive social capital in shaping...

source of value added, but closure can be critical to realizing the value buried in structural holes".

Continuing on the previous, Uphoff (1999) distinguishes between cognitive and structural social capital. Structural and cognitive social capital are complementary in the aspect in which structures help in translating norms and beliefs into a well-coordinated and goal-orientated behaviour (Uphoff 1999). Structural social capital involves various forms of social organisation, including roles, rules, precedents and procedures, as well as a variety of networks that contribute to co-operation. Although the structural social capital that refers to the social networks of individuals is an essential element in the creation and development of entrepreneurial ventures (Hoang and Antoncic 2003), the focus of this research is on the cognitive form of social capital and its impact on the entrepreneurial intention.

Cognitive processes play a significant role in explaining one's decision to become an entrepreneur (Baron 2004). An intention to start a business will form on the basis of the experience gained from direct contact with the object of attitude (such as one's acquaintance with entrepreneurs or self-employment) and from indirect learning of information from one's immediate and broader environment. In the context of entrepreneurship, the cognitive social capital of an individual refers to the values and beliefs about launching entrepreneurial ventures. Social capital, both structural and cognitive, may be in the function of bonding or bridging (Putnam 2001).

When it comes to one's close environment, it can be seen that family members and friends create and share language, narratives and values (Kuratko and Mathews 2004). Therefore, attitudes towards entrepreneurship are probably also shared in the close community (H2a). Regarding the subjective norm, if the close community appreciates entrepreneurship and/or already has entrepreneurs as its members, it will probably approve or even encourage its other members to become entrepreneurially active ( $\mathrm{H} 2 \mathrm{~b})$. Bonding social capital facilitates the evaluation of entrepreneurial opportunities, the access to and the use of resources that are necessary for the realization of entrepreneurial ventures and also provides the help and support of the close ones (Davidsson and Honig 2003). The access to these resources should increase an individual's perceived behavioural control (H2c). Linan and Santos (2007) confirmed the influence of bonding social capital on the perception of the desirability of entrepreneurial profession, and partially confirmed the impact on the perception of the feasibility of entrepreneurial ventures. On the basis of the existing literature, a possible indirect impact of 
bonding cognitive social capital on entrepreneurial intentions of students is assumed. Thus, the following set of hypotheses is established:

H2a:Bonding cognitive social capital has a positive impact on the attitude towards entrepreneurship.

H2b: Bonding cognitive social capital has a positive impact on subjective norm.

H2c:Bonding cognitive social capital has a positive impact on perceived behavioural control.

Bridging capital encompasses contacts with business associations, agencies at the national and local level, business angels, etc. which altogether could impact an individual's perception of the subjective norm (H3a). Also, it may facilitate an individual's access to entrepreneurial resources (H3b). For example, Kanas et al. (2009) found that the probability of self-employment among the immigrants in Netherlands is higher among those who have the access to bridging social capital.

On the other hand, Linan and Santos (2007) did not find the influence of bridging cognitive social capital on perceived desirability. Taking into consideration the emphasized importance of the availability of resources in the entrepreneurial environment and the social valuation of entrepreneurship, it is hypothesized that:

H3a:Bridging cognitive social capital has a positive impact on subjective norm.

H3b:Bridging cognitive social capital has a positive effect on perceived behavioural control.

Figure 1 shows the model that is going to be tested, with the corresponding hypotheses. 
Management, Vol. 22, 2017, 1, pp. 1-33

K. Vuković et al.: The role of bonding and bridging cognitive social capital in shaping...

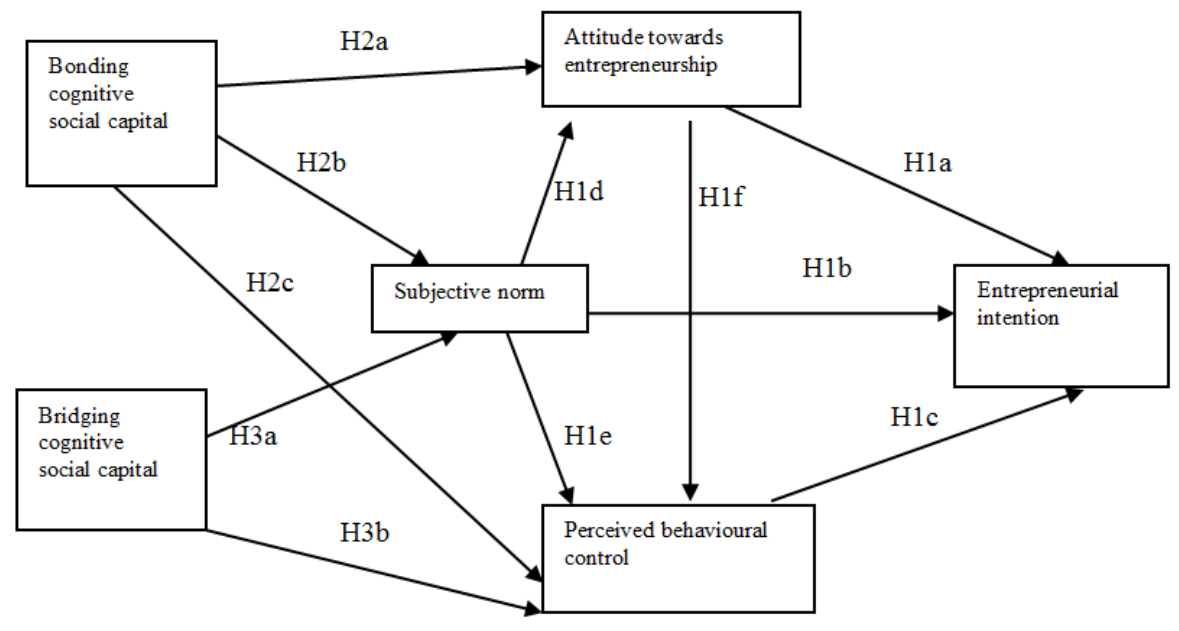

Figure 1. Entrepreneurial intention model

\section{METHODOLOGY}

\subsection{Data collection}

The data on entrepreneurial intentions of students, their predictors and social capital were collected by using the Entrepreneurial Intention Questionnaire (Linan et al. 2011.), which is based on the combined insights of both psychological and entrepreneurial research, as well as earlier empirical research in this area. The questionnaire was produced by the author.

The respondents were the students of the study programme of Economics of Entrepreneurship at the Faculty of Organization and Informatics in Varaždin, University of Zagreb, Croatia, and the students of the Faculty of Economics at the Ss. Cyril and Methodius University of Skopje, Macedonia. After eliminating incomplete questionnaires, our sample included 218 subjects (119 from Croatia and 99 from Macedonia), $74.3 \%$ of which were women. The average age of the respondents was 21.9 years. The suitability of the selected age group was based on the fact that the respondents would soon belong to a part of the population that shows the strongest entrepreneurial intentions - the highly educated people aged 25-34 (Reynolds et al. 2002). 
Management, Vol. 22, 2017, 1, pp. 1-33

K. Vuković et al: The role of bonding and bridging cognitive social capital in shaping...

\subsection{Variables used in the research}

The concepts of interest were examined in greatest part by evaluating statements on the Likert scale. This method enables better understanding of the constructs and provides better reliability compared to one-item evaluations.

\subsubsection{Entrepreneurial intention variables}

Entrepreneurial intention and its predictors (i.e., the attitude towards entrepreneurship, subjective norm and perceived behavioural control) were measured by using different statements that the respondents had to evaluate on the 7-point Likert scale, with 1 meaning total disagreement and 7 meaning total agreement with the statement. The questionnaire includes inverse statements in order to reduce any bias (Ray 1979), possibly appearing out of a tendency to agree with the statements that are being evaluated. In order to develop the constructs that would represent entrepreneurial intention and its predictors, two factor analyses were carried out: one for entrepreneurial intention and the other for its predictors. The advantage of factor analysis is that it eliminates the problem of correlated variables, so that further analysis is conducted on uncorrelated factors (Fulgosi 1998). Factor analyses were used to explain the variability of measured variables and eliminate those statements that do not load on the expected factor. In both cases the data was suitable for factor analyses, with the Kaiser-MeyerOlkin (KMO) measure of sampling adequacy amounting to 0.820 for entrepreneurial intention and 0.770 for its predictors.

The principal components method was used whereby the factors are linear transformations of the primary variables (Kurnoga Zivadinovic 2004). The first factor explains most of the total variance and each subsequent factor explains an ever smaller proportion of the total variance. According to the Kaiser criterion of factor selection, the factors whose eigenvalues are greater than one were chosen. In the social sciences, selecting a number of factors that explain at least $60 \%$ of the total variance of the initial variables is considered satisfying (Kurnoga Zivadinovic 2004). The Varimax rotation, after which factors remain independent, enabled an easier interpretation of the extracted factors. The reliability of each factor was measured with Cronbach's alpha coefficient (Nunally 1978), which is required to be at least 0.7 to confirm a factor's internal consistency.

The first factor analysis, which included the statements referring to entrepreneurial intention, resulted in one extracted factor (consisting of statements: I am ready to do anything to be an entrepreneur; I will make every 
effort to start and run my own business; I am determined to create a business venture in the future; My professional goal is to be an entrepreneur) that explained $65.8 \%$ of the total variance. Cronbach's alpha coefficient of 0.826 confirmed the factor's internal consistency.

Table 1. Factor analysis for entrepreneurial intention predictors

\begin{tabular}{|l|c|c|c|}
\hline \multicolumn{2}{|c|}{ Pattern Matrix } \\
\cline { 2 - 4 } & $\begin{array}{c}\text { Attitude } \\
\text { towards } \\
\text { entrepreneurship }\end{array}$ & $\begin{array}{c}\text { Perceived } \\
\text { behavioral } \\
\text { control }\end{array}$ & $\begin{array}{c}\text { Subjective } \\
\text { norm }\end{array}$ \\
\hline $\begin{array}{l}\text { My friends would approve of my decision to } \\
\text { start a business. }\end{array}$ & & & .890 \\
\hline $\begin{array}{l}\text { I am able to control the creation process of a } \\
\text { new business. }\end{array}$ & & .736 & \\
\hline $\begin{array}{l}\text { My immediate family would approve of my } \\
\text { decision to start a business. }\end{array}$ & & & .500 \\
\hline $\begin{array}{l}\text { My colleagues would approve of my decision } \\
\text { to start a business. }\end{array}$ & .902 & & .872 \\
\hline $\begin{array}{l}\text { Among various options, I would rather be } \\
\text { anything but an entrepreneur. - reversed }\end{array}$ & & .780 & \\
\hline $\begin{array}{l}\text { If I tried to start a business, I would have a } \\
\text { high chance of being successful. }\end{array}$ & .777 & & \\
\hline $\begin{array}{l}\text { Being an entrepreneur would give me great } \\
\text { satisfaction. }\end{array}$ & .576 & & \\
\hline $\begin{array}{l}\text { Being an entrepreneur implies more } \\
\text { advantages than disadvantages to me. }\end{array}$ & & $\mathbf{0 . 6 7 5}$ & $\mathbf{0 . 6 8 9}$ \\
\hline $\begin{array}{l}\text { I know all about the practical details needed } \\
\text { to start a business. }\end{array}$ & & & \\
\hline Cronbach's alpha coefficient & $\mathbf{0 . 6 9 3}$ & & \\
\hline
\end{tabular}

Note. Extraction method: principal component analysis. Rotation method: Oblimin with Kaiser normalization. Rotation converged in 8 iterations.

The second factor analysis, which included the statements referring to entrepreneurial intention predictors, resulted in three factors that together explain $57.9 \%$ of the total variance. The three extracted factors were: attitude towards entrepreneurship with Cronbach's alpha coefficient of 0.693; subjective norm with Cronbach's alpha coefficient of 0.689; and perceived behavioural control, with Cronbach's alpha coefficient of 0.604. Evidently, the factor of perceived behavioural control lacks reliability and the statements regarding this construct should be revised in further research. 
Management, Vol. 22, 2017, 1, pp. 1-33

K. Vuković et al: The role of bonding and bridging cognitive social capital in shaping...

\subsubsection{Social capital variables}

Because of the many different approaches and numerous definitions of social capital and related categories in the pertaining literature, it is necessary to set a clear link between the definition and operationalization (Baron and Hannan 1994) to ensure the comparability of our results with the results of other studies.

Bonding cognitive social capital was measured using the following two variables: acquaintance with entrepreneurs and closer valuation. Acquaintance with entrepreneurs covers both quantitative and qualitative aspects of these potential role models. It was measured whether our respondents knew any entrepreneurs in the circle of their family or friends and whether they had met an entrepreneur at their workplace or in some other way. This part of our evaluation shows the quantitative aspect of entrepreneurial exposure - the respondents gave information on the extent to which they were familiar with a particular entrepreneurial activity (from 1 - not at all to 7 - extremely well). In the second part of our evaluation, the respondents were asked whether they considered those entrepreneurs known to them as 'good ones' (from 1 - not at all to 7 - extremely good).

It is assumed that the impact of structural social capital on entrepreneurial intention and its predictors is strengthened both by the extent to which a respondent is familiar with an entrepreneurial activity and by the intensity of a respondent's perception of an entrepreneur's successfulness. Therefore, those two variables were multiplied to obtain a new variable that encompasses both the quantitative and the qualitative aspect of structural social capital. In this way it is captured that it is not only the acquaintance with an entrepreneur that matters, but also the perception that a potential entrepreneur forms of this entrepreneur's quality. The more favourable one's perception is, the stronger the positive influence of the structural social capital will be, and vice versa. Consequently, these four new variables were calculated: family entrepreneur, friend entrepreneur, employer entrepreneur and other entrepreneur. Since those variables do not need to be correlated in order to describe a respondent's acquaintance with entrepreneurs, together they create a formative variable in the model, named acquaintance with entrepreneurs. Closer valuation refers to a respondent's perception of how their family, friends and colleagues valuate entrepreneurship.

Bridging cognitive social capital was measured by using two variables: acquaintance with entrepreneurial environment and social valuation of entrepreneurship. Acquaintance with entrepreneurial environment covered 
statements that reveal the level of familiarity with the private and public bodies that support entrepreneurship (such as business angels and government agencies), special training for young entrepreneurs, loans under special conditions, entrepreneurial zones and business incubators. Social valuation measures respondents' perception of the valuation of entrepreneurship by their society. The constructs described above (acquaintance with entrepreneurial environment, closer valuation and social valuation), were obtained as the extracted factors from the factor analysis (Table 2).

Table 2. Factor analysis for cognitive social capital variables

\begin{tabular}{|c|c|c|c|}
\hline \multicolumn{4}{|c|}{ Pattern Matrix $^{1}$} \\
\hline & \multicolumn{3}{|c|}{ Component } \\
\hline & $\begin{array}{c}\text { Acquaintance with } \\
\text { entrepreneurial } \\
\text { environment }\end{array}$ & $\begin{array}{c}\text { Closer } \\
\text { valuation }\end{array}$ & $\begin{array}{c}\text { Social } \\
\text { valuation }\end{array}$ \\
\hline Public support bodies &, 852 & & \\
\hline Specific training for young entrepreneurs & 650 & & \\
\hline Loans under especially favourable terms & ,765 & & \\
\hline Technical aid for business start-ups & 893 & & \\
\hline Business centres & 882 & & \\
\hline $\begin{array}{l}\text { My immediate family values entrepreneurial } \\
\text { activity above other activities and careers. }\end{array}$ & & 684 & \\
\hline $\begin{array}{l}\text { The entrepreneur's role in the economy is } \\
\text { generally undervalued in my country. - } \\
\text { reversed }\end{array}$ & & & ,758 \\
\hline $\begin{array}{l}\text { My friends value entrepreneurial activity } \\
\text { above other activities and careers. }\end{array}$ & & 865 & \\
\hline $\begin{array}{l}\text { Most people in my country consider it } \\
\text { unacceptable to be an entrepreneur. - reversed }\end{array}$ & & & ,700 \\
\hline $\begin{array}{l}\text { My colleagues value entrepreneurial activity } \\
\text { above other activities and careers. }\end{array}$ & & 843 & \\
\hline $\begin{array}{l}\text { It is commonly thought in my country that } \\
\text { entrepreneurs take advantage of others. - } \\
\text { reversed }\end{array}$ & & & ,752 \\
\hline Cronbach's alpha & 0.874 & 0.753 & 0.595 \\
\hline
\end{tabular}

Note. Extraction method: principal component analysis. Rotation method: Oblimin with Kaiser normalization. Rotation converged in 4 iterations.

The Kaiser-Meyer-Olkin (KMO) measure of sampling adequacy amounted to 0.748 , which confirmed the appropriateness of the planned method. The extracted factors explain $65.00 \%$ of the total variance. Acquaintance with entrepreneurial environment and closer valuation proved to be reliable constructs, with Cronbach's alpha coefficients of 0.874 and 0.753 , respectively. Social valuation is less reliable, with Cronbach's alpha coefficient of 0.595 and should 
be revised in future research. This is the confirmation of the problem related to the social valuation measurement reported by Linan et al. (2011). Consequently, the inclusion of social valuation in the testing of entrepreneurial intention model should be done with caution.

\subsubsection{Control variables}

The following control variables were used in the model: gender $(0=$ female, $1=$ male $)$, work experience $(0=$ no experience, $1=$ has work experience $)$ and self-employment experience $(0=$ no self-employment experience, $1=$ has selfemployment experience). Gender has shown to be an important variable when analyzing entrepreneurial intention model (de la Cruz Sánchez-Escobedo et al. 2011, Diaz Casero et al. 2012). Work experience and self-employment experience may also influence entrepreneurial intention (Linan et al. 2011).

\subsection{Testing the hypothesized model of entrepreneurial intention}

Before testing the model of entrepreneurial intentions, it was determined whether there were significant differences between the Croatian and Macedonian sample in latent and control variables. The difference in the means test (t-test) revealed several significant differences between the two samples, which will be explained in the findings.

In behavioural sciences, the use of the structural equation modelling technique has increased substantially since the last decade of the 20th century (Shook et al. 2004). Structural equation modelling forms a series of presumed causal relationships between variables in a single hypothesis on the model of statistical dependence (Pugesek 2003). The technique is a combination of confirmatory factor analysis and causal modelling that examines the network of relationships between observed constructs. Complicated causal networks obtained by SEM characterize real-world processes better than simple correlation-based models (Gefen et al. 2011).

The tested model is shown in Figure 1. The model consists of eight latent variables, seven of which are reflective and one (acquaintance with entrepreneurs) is formative (Haenlein and Kaplan 2004). The formative variable was obtained by combining these four manifest variables: family entrepreneur, friend entrepreneur, employer entrepreneur and other entrepreneur. Since these four variables are not caused by a common construct, they cannot belong to a reflective latent variable, but together form a formative latent variable. 


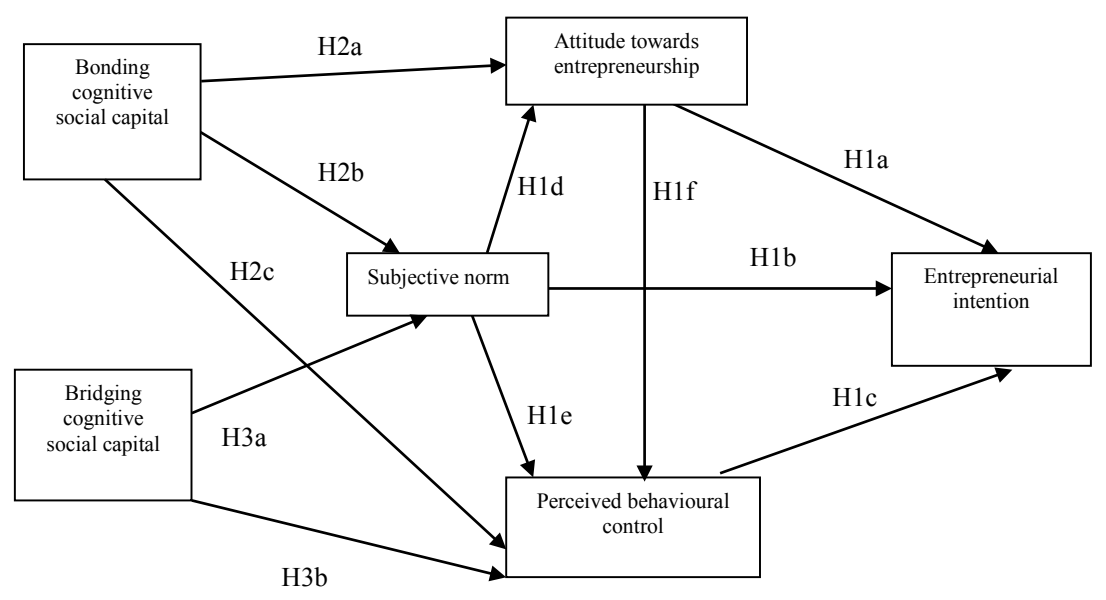

Figure 1. Entrepreneurial intention model

In this study, the modelling was carried out using the partial least squares technique, performed on the SmartPLS software package (Ringle et al. 2005). The application of this method is suggested when a model is complex and includEs formative constructs, and when the sample size is relatively small (Reinartz et al. 2009, Hair et al. 2011). Our model has the mentioned characteristics.

\section{FINDINGS}

The means test (t-test) revealed significant differences between the Croatian and Macedonian sample regarding the variables in the model. The results are presented in Table 3. On a scale of 1 to 7, Macedonian students score higher in entrepreneurial intention (4.99) than Croatian students (4.41). Entrepreneurial intention is supported by more positive attitudes towards entrepreneurship among Macedonian students (6.05) compared to Croatian students (5.54).

Macedonian students also perceive their close environment (4.55) and the whole Macedonian society (4.66), as more prone to entrepreneurship, compared to Croatian students, whose estimates are lower (4.08 and 3.94, respectively). These findings are in line with our introductory remarks about Macedonia as a more entrepreneurial society. 
Management, Vol. 22, 2017, 1, pp. 1-33

$\mathrm{K}$. Vuković et al: The role of bonding and bridging cognitive social capital in shaping...

Table 3. T-test for equality of means

\begin{tabular}{|c|c|c|c|c|c|c|c|}
\hline & & \multicolumn{2}{|c|}{$\begin{array}{c}\text { Levene's Test } \\
\text { for Equality of } \\
\text { Variances }\end{array}$} & \multicolumn{4}{|c|}{ T-test for equality of means } \\
\hline & & $\mathbf{F}$ & Sig. & $\mathbf{t}$ & df & $\begin{array}{l}\text { Sig. (2- } \\
\text { tailed) }\end{array}$ & $\begin{array}{c}\text { Mean } \\
\text { Difference }\end{array}$ \\
\hline \multirow{2}{*}{$\begin{array}{l}\text { Entrepreneurial } \\
\text { intention }\end{array}$} & Yes &, 392 &, 532 & $-3,312$ & 214 &, 001 &,- 44214924 \\
\hline & No & & & $-3,295$ & 203,407 & 001 &,- 44214924 \\
\hline \multirow{2}{*}{$\begin{array}{l}\text { Attitude towards } \\
\text { entrepreneurship }\end{array}$} & Yes & 2,088 & ,150 & $-4,811$ & 214 & ,000 &,- 62555702 \\
\hline & No & & & $-4,735$ & 189,975 & ,000 &,- 62555702 \\
\hline \multirow{2}{*}{ Subjective norm } & Yes & 077 & ,782 &, 532 & 214 &, 595 & ,07272969 \\
\hline & No & & & 530 & 204,451 & 597 & ,07272969 \\
\hline \multirow{2}{*}{$\begin{array}{l}\text { Perceived } \\
\text { behavioural } \\
\text { control }\end{array}$} & Yes & 3,465 & 064 & 1,073 & 214 & ,284 &, 14653851 \\
\hline & No & & & 1,055 & 187,838 & ,293 &, 14653851 \\
\hline \multirow{2}{*}{ Closer valuation } & Yes & 5,540 & ,020 & $-3,718$ & 202 &, 000 &,- 50909253 \\
\hline & No & & & $-3,593$ & 159,824 & ,000 &,- 50909253 \\
\hline \multirow{2}{*}{ Social valuation } & Yes & 17,561 & 000 & $-4,768$ & 202 & ,000 &,- 63974479 \\
\hline & No & & & $-4,578$ & 153,638 & ,000 &,- 63974479 \\
\hline \multirow{2}{*}{$\begin{array}{l}\text { Acquaintance with } \\
\text { entrepreneurial } \\
\text { environment }\end{array}$} & Yes & 1,835 & ,177 & 3,982 & 202 &, 000 &, 54266472 \\
\hline & No & & & 3,930 & 179,063 &, 000 &, 54266472 \\
\hline \multirow{2}{*}{ Family entrepreneur } & Yes & ,547 & ,461 & 2,496 & 96 & ,014 & 5,75510 \\
\hline & No & & & 2,496 & 94,903 &, 014 & 5,75510 \\
\hline \multirow{2}{*}{ Friend entrepreneur } & Yes & 1,374 & 244 & 3,559 & 86 & ,001 & 8,72727 \\
\hline & No & & & 3,436 & 60,306 & 001 & 8,72727 \\
\hline \multirow{2}{*}{$\begin{array}{l}\text { Employer } \\
\text { entrepreneur }\end{array}$} & Yes &, 555 & ,461 & ,754 & 40 & ,455 & 2,86270 \\
\hline & No & & & ,744 & 36,104 & 461 & 2,86270 \\
\hline \multirow{2}{*}{ Other entrepreneur } & Yes & 1,770 & ,190 & 2,937 & 49 & ,005 & 8,92679 \\
\hline & No & & & 3,197 & 36,098 & ,003 & 8,92679 \\
\hline \multirow{2}{*}{ Work experience } & Yes & 28,695 &, 000 & 2,682 & 214 &, 008 &, 169 \\
\hline & No & & & 2,715 & 213,919 &, 007 & ,169 \\
\hline \multirow{2}{*}{$\begin{array}{l}\text { Self-employment } \\
\text { experience }\end{array}$} & Yes & 1,361 & ,245 &,- 582 & 213 & ,561 &,- 016 \\
\hline & No & & &,- 574 & 191,225 & ,567 &,- 016 \\
\hline \multirow{2}{*}{ Gender } & Yes & 1,145 & ,286 &, 533 & 208 & ,595 & ,034 \\
\hline & No & & & 534 & 206,639 & ,594 & ,034 \\
\hline
\end{tabular}

Note. Bold numbers signify the row relevant for means comparison.

On the other hand, Croatian students in the sample had more work experience ( $40 \%$ of Croatian students vs. $23 \%$ of Macedonian students) and were also more often and better acquainted with the entrepreneurial activities of their family members, friends and other people. In addition, Croatian students were more familiar with the entrepreneurial environment (3.58), compared to Macedonian students (3.17), although their knowledge could be substantially improved in both countries. 
The reason for these differences probably lies in the fact that the curriculum of Croatian students is focused on entrepreneurship, which opens up different opportunities for meeting entrepreneurs, learning about the entrepreneurial environment and gaining work experience. After examining the main differences in observed constructs between the two countries, the entrepreneurial intention model shown in Figure 1 was tested using the data for the two countries (combined and separate).

Our evaluation of the model consists of the reliability and validity analysis of the constructs and the evaluation of the structural model. The reliability analysis estimates the consistency of the latent variables. In order for a latent variable to be reliable, both the values of composite reliability and the loadings of indicators should be greater than 0.7 (Hair et al. 2011). The convergent validity of constructs is measured by the average variance extracted, which should be greater than 0.5 . This means that the latent variable explains more than half of the variance of its indicators (Hair et al. 2011). Discriminant validity was tested according to the Fornell-Larcker criterion (1981), which says that a latent variable should share more variance with its indicators (average variance extracted) than with any other latent variable in the model. Discriminant validity also assumes that an indicator's loading should be higher than all of its cross loadings (Hair et al. 2011). The reliability and validity analysis of reflective constructs in our model is shown in Table 4 and confirms that the constructs are both reliable and valid.

Table 4. Reliability and validity analysis of reflective constructs

\begin{tabular}{|c|c|c|c|c|}
\hline \multirow{3}{*}{$\begin{array}{l}\text { Reflective } \\
\text { construct }\end{array}$} & \multirow{3}{*}{ 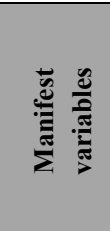 } & \multicolumn{2}{|c|}{ Reliability analysis } & \multirow{2}{*}{ Validity analysis } \\
\hline & & \multirow{2}{*}{$\begin{array}{l}\text { Composite } \\
\text { reliability }\end{array}$} & \multirow{2}{*}{$\begin{array}{c}\text { Indicator loading } \\
\text { (should be higher } \\
\text { than 0.70) }\end{array}$} & \\
\hline & & & & $\begin{array}{c}\text { Convergent validity } \\
\text { (AVE) }>0.50 ?\end{array}$ \\
\hline \multirow{4}{*}{$\begin{array}{l}\text { Entreprene- } \\
\text {-urial } \\
\text { intention }\end{array}$} & A4 & \multirow{4}{*}{0.8849} & 0.7921 & \multirow{4}{*}{0.6578} \\
\hline & A6 & & 0.8141 & \\
\hline & A13 & & 0.8064 & \\
\hline & A17 & & 0.8306 & \\
\hline \multirow{3}{*}{$\begin{array}{l}\text { Attitudes } \\
\text { towards the } \\
\text { behaviour } \\
\end{array}$} & A12-rev & \multirow{3}{*}{0.8283} & 0.6914 & \multirow{3}{*}{0.6189} \\
\hline & A15 & & 0.8804 & \\
\hline & A18 & & 0.7741 & \\
\hline \multirow{3}{*}{$\begin{array}{l}\text { Subjective } \\
\text { norm }\end{array}$} & $\mathrm{A} 3$ & \multirow{3}{*}{0.8281} & 0.7650 & \multirow{3}{*}{0.6163} \\
\hline & $\mathrm{A} 8$ & & 0.7788 & \\
\hline & A11 & & 0.8076 & \\
\hline
\end{tabular}


Management, Vol. 22, 2017, 1, pp. 1-33

K. Vuković et al: The role of bonding and bridging cognitive social capital in shaping...

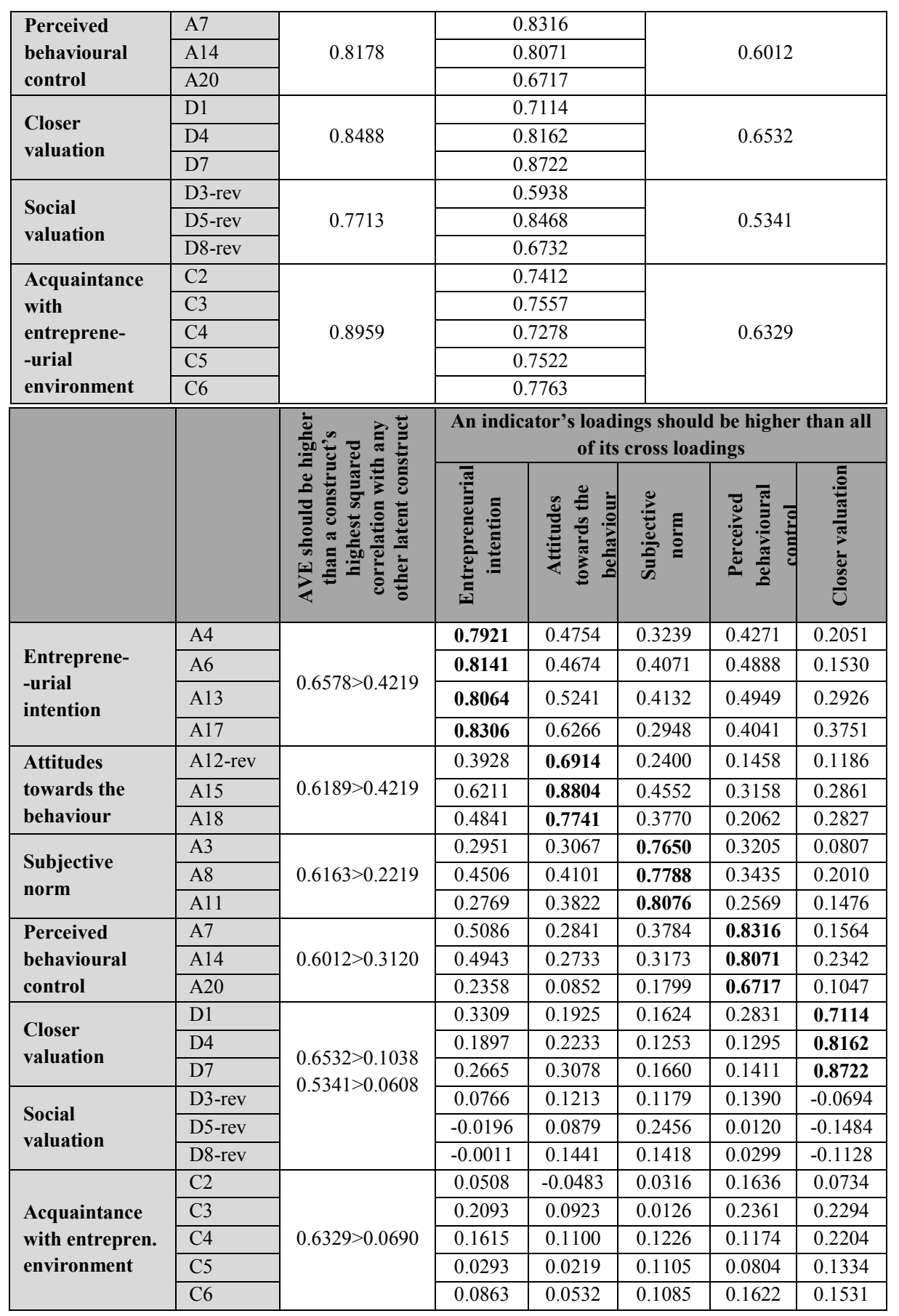


Management, Vol. 22, 2017, 1, pp. 1-33

K. Vuković et al.: The role of bonding and bridging cognitive social capital in shaping...

\begin{tabular}{|c|c|c|c|c|}
\hline & & 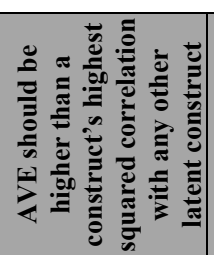 & 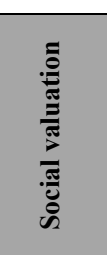 & 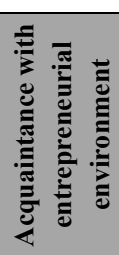 \\
\hline \multirow{4}{*}{$\begin{array}{l}\text { Entreprene- } \\
\text {-urial } \\
\text { intention }\end{array}$} & A4 & \multirow{4}{*}{$0.6578>0.4219$} & 0.0714 & 0.1402 \\
\hline & A6 & & 0.0650 & 0.1058 \\
\hline & A13 & & 0.0116 & 0.1069 \\
\hline & A17 & & -0.0961 & 0.1497 \\
\hline \multirow{3}{*}{$\begin{array}{l}\text { Attitudes } \\
\text { towards the } \\
\text { behaviour }\end{array}$} & A12-rev & \multirow{3}{*}{$0.6189>0.4219$} & 0.1365 & -0.0095 \\
\hline & A15 & & 0.0953 & 0.0077 \\
\hline & $\mathrm{A} 18$ & & 0.1319 & 0.1430 \\
\hline \multirow{3}{*}{$\begin{array}{l}\text { Subjective } \\
\text { norm }\end{array}$} & $\mathrm{A} 3$ & \multirow{3}{*}{$0.6163>0.2219$} & 0.2052 & 0.0026 \\
\hline & $\mathrm{A} 8$ & & 0.1932 & 0.0584 \\
\hline & A11 & & 0.1834 & 0.1293 \\
\hline \multirow{3}{*}{$\begin{array}{l}\text { Perceived } \\
\text { behavioural } \\
\text { control }\end{array}$} & A7 & \multirow{3}{*}{$0.6012>0.3120$} & 0.0908 & 0.1363 \\
\hline & A14 & & -0.0225 & 0.1301 \\
\hline & $\mathrm{A} 20$ & & 0.0894 & 0.2940 \\
\hline \multirow{3}{*}{$\begin{array}{l}\text { Closer } \\
\text { valuation }\end{array}$} & D1 & \multirow{6}{*}{$\begin{array}{l}0.6532>0.1038 \\
0.5341>0.0608\end{array}$} & -0.1832 & 0.1340 \\
\hline & D4 & & -0.1028 & 0.1484 \\
\hline & D7 & & -0.1097 & 0.2191 \\
\hline \multirow{3}{*}{$\begin{array}{l}\text { Social } \\
\text { valuation }\end{array}$} & D3-rev & & 0.5938 & -0.1416 \\
\hline & D5-rev & & 0.8468 & -0.1195 \\
\hline & D8-rev & & 0.6732 & -0.1269 \\
\hline \multirow{5}{*}{$\begin{array}{l}\text { Acquaintance } \\
\text { with entrepren. } \\
\text { environment }\end{array}$} & $\mathrm{C} 2$ & \multirow{5}{*}{$0.6329>0.0690$} & -0.1267 & 0.7412 \\
\hline & $\mathrm{C} 3$ & & -0.0848 & 0.7557 \\
\hline & $\mathrm{C} 4$ & & -0.1406 & 0.7278 \\
\hline & $\mathrm{C} 5$ & & -0.2089 & 0.7522 \\
\hline & C6 & & -0.1630 & 0.7763 \\
\hline
\end{tabular}

Regarding a formative construct, it is important that all the indicator weights are significant. In our model, there is one formative construct (acquaintance with entrepreneurs) with the belonging indicators: family entrepreneur, friend entrepreneur, employer entrepreneur and other entrepreneur. However, the evaluation of this construct showed that only two indicators - family entrepreneur and friend entrepreneur - have significant weights and were retained in the model. Also, the indicator's variance inflation factor (VIF) value should be less than 5 (Hair et al. 2011), so the problem of multicollinearity would not be pronounced. For our formative construct those conditions are satisfied, as presented in Table 5. 
Management, Vol. 22, 2017, 1, pp. 1-33

$\mathrm{K}$. Vuković et al: The role of bonding and bridging cognitive social capital in shaping...

Table 5. Evaluation of formative constructs (number of bootstrap samples=5000)

\begin{tabular}{|l|l|l|l|}
\hline Formative construct & Manifest variables & Weight & $\begin{array}{c}\text { Multicolinearity } \\
(\text { VIF < 5) }\end{array}$ \\
\hline $\begin{array}{l}\text { Acquaintance with } \\
\text { entrepreneurs }\end{array}$ & Family entrepreneur & $0,8506^{* *}$ & 1.0000 \\
\cline { 2 - 4 } & Friend entrepreneur & $0,4723^{* *}$ & \\
\hline
\end{tabular}

$* *$ significant at the 0.05 level

The main dependent variable in the model is entrepreneurial intention. Its predictors and social capital variables managed to explain $59.8 \%$ of its variance. In partial least squares (PLS) path modelling, goodness-of-fit indices are not suitable for model validation. Instead, researchers should carefully evaluate the significance of the path coefficients in order to decide which paths to leave in the model and which to discard (Henseler and Sarstedt 2012). The modelling results for the whole sample are shown in Figure 2.

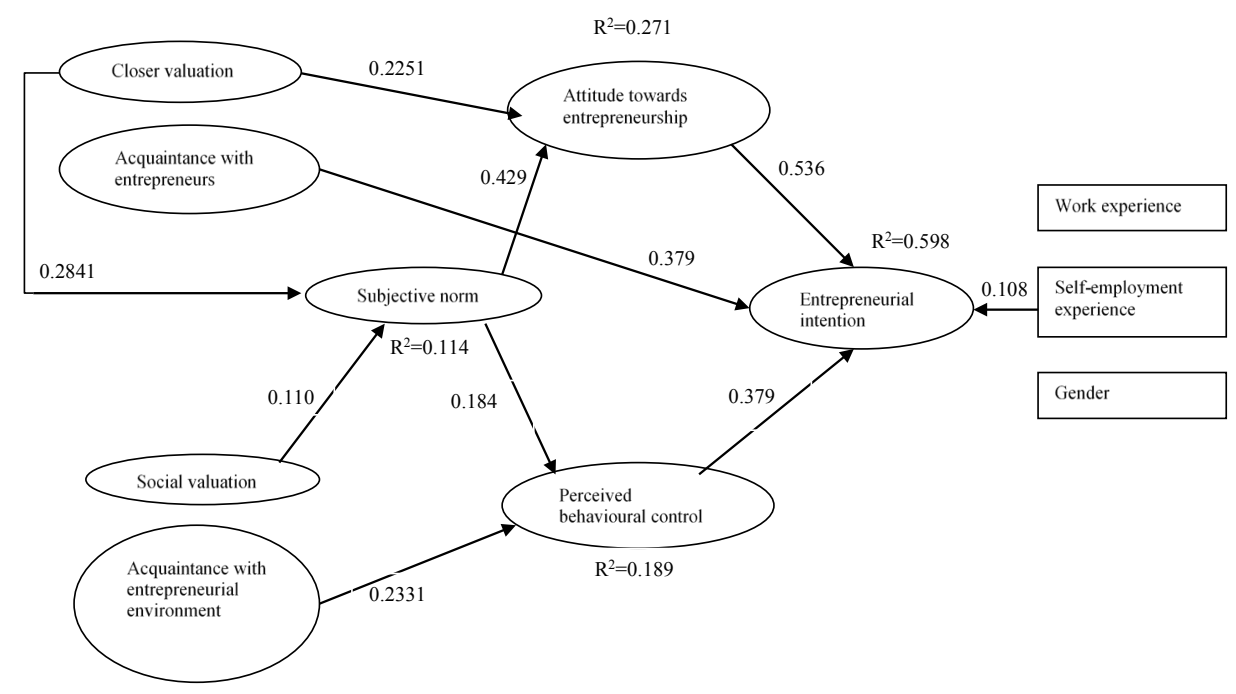

Note. Only significant $(\mathrm{p}<0.05)$ path coefficients are shown.

Figure 2. Results for the joint sample

Figures 3 and 4 show the results for Croatian and Macedonian sample separately. The numbers on the arrows are the regression coefficients and only those reaching the level of statistical significance are shown. 


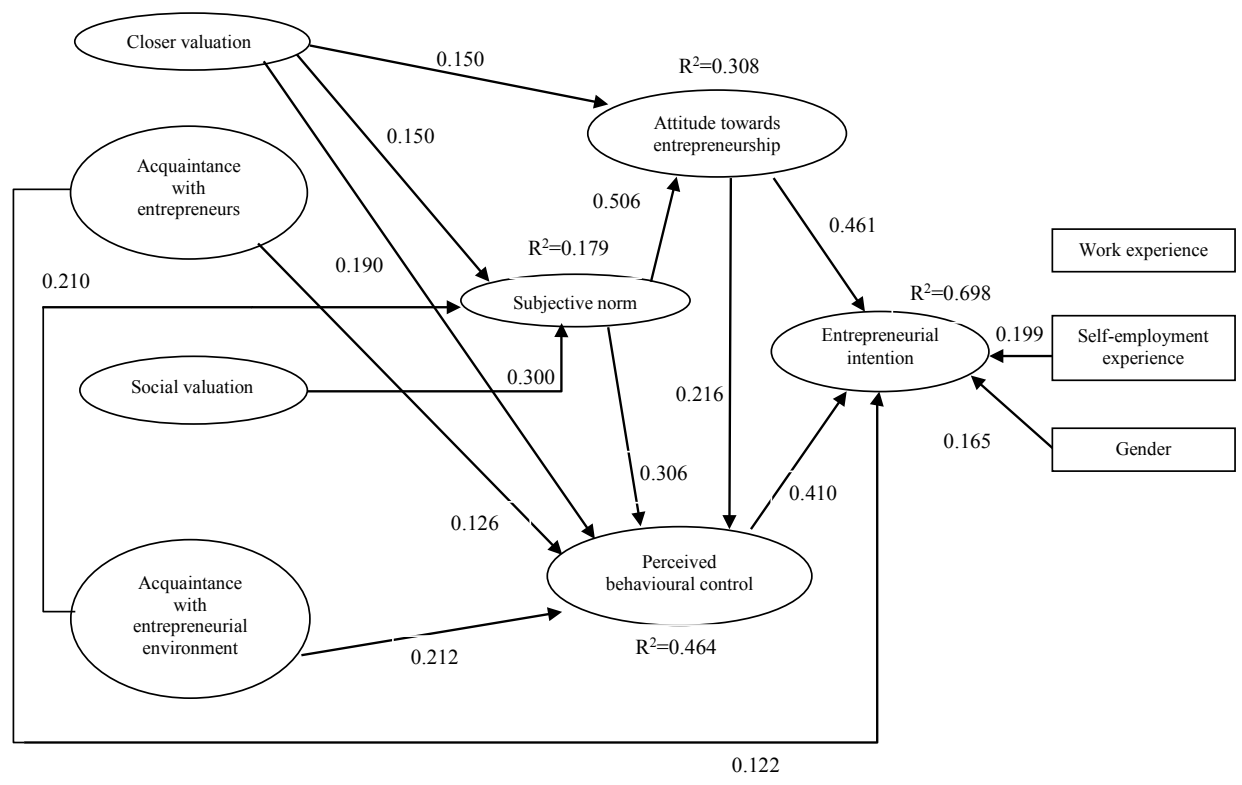

Note. Only significant $(\mathrm{p}<0.05)$ path coefficients are shown.

Figure 3. Results for Croatian sample

The attitude towards entrepreneurship has a significant positive impact on entrepreneurial intention in both samples, which confirms the hypothesis H1a. The influence of subjective norm on entrepreneurial intention is not significant in the Croatian sample, unlike the Macedonian one, which partially confirms the hypothesis H1b. Perceived behavioural control has a significant positive impact on entrepreneurial intentions in both countries, which confirms the hypothesis H1c.

In both samples the subjective norm impacts entrepreneurial intention through the attitude towards entrepreneurship (H1d confirmed) and the perceived behavioural control (H1e confirmed). In the Croatian sample, there was significance in the relationship between the attitude towards entrepreneurship and perceived behavioural control, which partially confirms the hypothesis H1f. The results show the robustness of the model in different surroundings with relationship between the subjective norm and entrepreneurial intention with the attitude towards entrepreneurship and perceived behavioural control being less stable. 
The bonding social capital was represented by two variables: closer valuation and acquaintance with entrepreneurs. In both samples, closer valuation positively impacts the attitudes of students, while there is no significant relationship between acquaintance with entrepreneurs and the attitudes. Thus, the hypothesis $\mathrm{H} 2 \mathrm{a}$ is partially confirmed. Regarding the positive impact of bonding social capital on subjective norm, the hypothesis $\mathrm{H} 2 \mathrm{~b}$ is confirmed for both samples. Closer valuation has a significant positive impact on the perceived behavioural control, but only for Croatian sample so the hypothesis $\mathrm{H} 2 \mathrm{c}$ is partially confirmed. In all the samples, the variable of acquaintance with entrepreneurs positively impacts entrepreneurial intentions in a direct way, and not through its predictors.

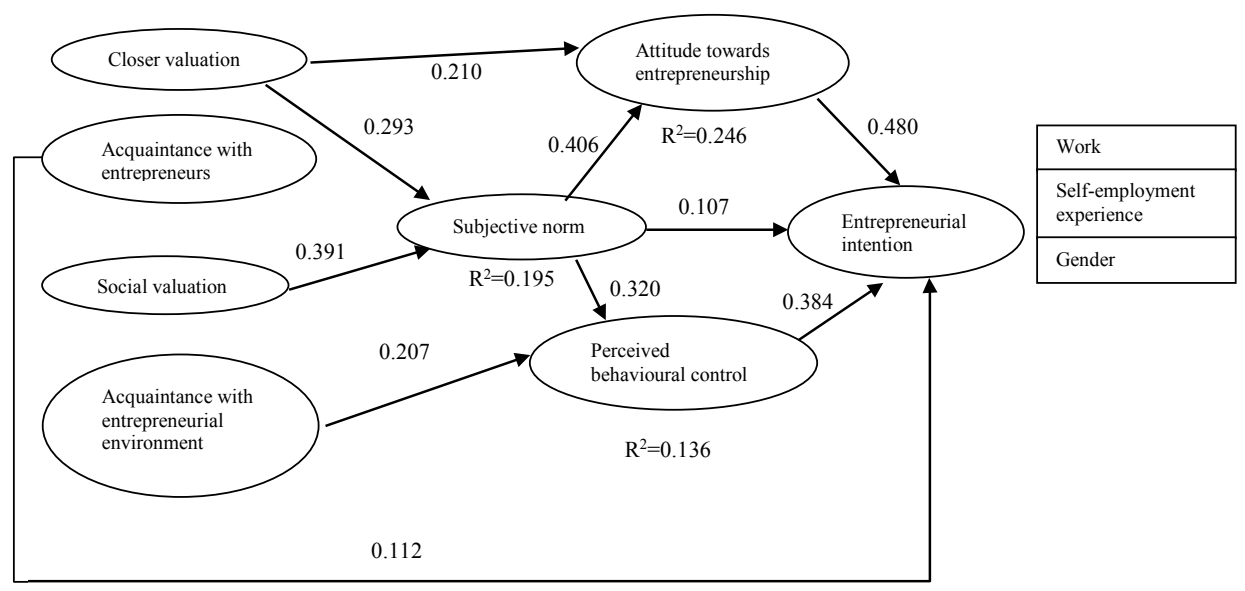

Note. Only significant $(\mathrm{p}<0.05)$ path coefficients are shown.

Figure 4. Results for Macedonian sample

The bridging social capital was described by two variables: social valuation and acquaintance with entrepreneurial environment. Bridging social capital showed to have positive impact on the subjective norm, which confirms the hypothesis H3a. The variable of acquaintance with entrepreneurial environment has a steady, positive impact on the perceived behavioural control in all the samples. However, the perceived behavioural control is not influenced by social valuation. Thus, the hypothesis H3b is partially confirmed.

The control variables indicate the fact that, in the Croatian sample, the male students exhibit more entrepreneurial intention than the female students. Furthermore, their self-employment experience supports entrepreneurial intentions among Croatian students. 


\section{CONCLUSION}

The findings showed that the influence of subjective norm on entrepreneurial intention is not significant in the Croatian sample, unlike the Macedonian one. This is a confirmation of the unstable relationship between subjective norm and entrepreneurial intention. In the western countries subjective norms proved to be a weaker predictor of behavioural intention (Krueger et al. 2000, Autio et al. 2001), while subjective norms were significantly predictive for the population of students in India and Russia (Tkachev and Kolvereid 1999). If not directly, the influence of subjective norms exists indirectly through their impact on attitudes and perceived behavioural control (Linan et al. 2011). In both samples, the subjective norm impacts entrepreneurial intention through the attitude towards entrepreneurship and the perceived behavioural control.

The rest of the basic entrepreneurial intention model is more robust regardless of the analysed country. Attitude towards entrepreneurship and perceived behavioural control have a significant positive impact on entrepreneurial intentions in both Croatia and Macedonia.

The interesting finding that contributes to the existing literature is that in both samples, acquaintance with entrepreneurs positively impacts entrepreneurial intentions in a direct way, and not through its predictors. Thus, the acquaintance with entrepreneurs seems to be an important independent predictor of entrepreneurial intention. The reason for this lies in the way it was measured taking into account both quantitative and qualitative aspects of potential role models in entrepreneurship. Thus, further research should include the measurement of acquaintance with entrepreneurs when analysing the entrepreneurial intention formation.

The findings indicate that bridging and bonding social capital could be significant enhancers of entrepreneurial intention. This is in line with other empirical research suggesting that social capital has an impact on entrepreneurial intentions of young people (Liñán and Santos, 2007; Sharma, 2014). Our findings also show that Croatian students were more familiar with the entrepreneurial environment. The reason for these differences probably lies in the fact that the curriculum of Croatian students is focused on entrepreneurship, which opens up different opportunities for meeting entrepreneurs, learning about the entrepreneurial environment and gaining work experience.

The fact that those individuals who have poor bonding social capital may get their chance through bridging social capital seems to be a good indicator. 
Therefore, bridging social capital can be regarded as inclusive. It can provide individuals with the resources available outside of their usual community. Since knowledge and information are very important tools in entrepreneurship, bridging social capital that forms in an entrepreneurial environment can encourage young people in their self-employment efforts and help in realizing their entrepreneurial intentions.

The problem of youth unemployment shifts the focus on education and the issue of the kind of knowledge and skills that young people should acquire in order to conform to an environment of uncertainty, complexity and quick changes. Following this line of thought, our research offers some interesting insights that can be used to encourage inclusiveness of the young educated population.

Furthermore, our research can be useful pedagogically because it implies several possible measures of enhancing the efficiency of entrepreneurial education. The results show that the acquaintance with one's entrepreneurial environment has a significant positive impact on the perceived behavioural control. This clearly suggests that students should be taught more about the topics of private associations (such as the Croatian network of business angels), public support systems (like SMEs and the Entrepreneurship Policy Center in Croatia or the Agency for Promotion of Entrepreneurship in Macedonia) and entrepreneurial zones/incubators. This would increase students' perception of the feasibility of entrepreneurship and it would also indirectly increase entrepreneurial intentions. Curricula should provide detailed information on the existing institutional support, which could also include visits to entrepreneurial zones, incubators and centres.

On average, male students in Croatia show higher entrepreneurial intention compared to female students. Therefore, the relevant educational institutions should provide students with good examples of women entrepreneurs, such as inviting successful women entrepreneurs as guest lecturers. From the entrepreneurial policy perspective, the strengthening of entrepreneurial capacity could be achieved by including under-represented groups in entrepreneurial activities. One of those groups are women. So, the education for entrepreneurship needs to find ways to encourage female students in recognizing their selfefficacy.

Lower level of self-efficacy of female students shows the need for entrepreneurship education to prevent gender inequality reproduction in the field of entrepreneurship. If entrepreneurship and entrepreneurial education are put in 
the Bourdieu's theoretical framework, then the education and curricula can play a significant role in the capital conversion process. Cultural capital acquired at a university can then be converted into social capital (bridging social capital between distant actors of society) and then social capital can be converted into economic capital.

\subsection{Limitations and further research}

The limitation of our study is the relatively small sample that includes only the students of business studies. Future research should be conducted on a larger sample of students of different studies that could test the impact of education on entrepreneurial intention.

The contact information obtained from the surveyed students offers us a possibility to follow their career paths and test the connection between entrepreneurial intention and actual behaviour (such as self-employment and businesses creation) through a longitudinal study.

Furthermore, the differences in attitude towards entrepreneurship, closer valuation and social valuation of entrepreneurship that were found between the sampled Croatian and Macedonian students, indicate the possible influence of national cultures, values and norms on entrepreneurial intention. Although the sampled Croatian students attend more courses that are explicitly oriented towards entrepreneurship, they have lower entrepreneurial intention compared to the sampled Macedonian students, who do not have this specialized syllabus. These results do not confirm that the entrepreneurial education of Croatian students is ineffective -a longitudinal study would be needed to test this - but they certainly present a good material for further research. For example, the question of the relative importance of entrepreneurial education compared to other determinants of entrepreneurial intention and its predictors, such as social values and norms, is worth further research.

In studies of entrepreneurial intention, social norms proved to be a weaker predictor of behavioural intention (Krueger et al. 2000, Autio et al. 2001). In the study conducted by Moriano et al. (2012), social norms were significantly predictive for the population of students in the Netherlands and India, as well as in the research among the population of students in Russia (Tkachev and Kolvereid 1999). If not directly, the influence of subjective norms exists indirectly through their impact on attitudes and perceived behavioural control (Linan et al. 2011). 


\section{REFERENCES}

1. Aidis, R., 2005. Entrepreneurship in Transition Countries: A Review (online), Centre for the Study of Economic and Social Change in Europe. http://discovery.ucl.ac.uk/17505/1/17505.pdf (Accessed 24 March 2013).

2. Ajzen, I., 1988. Attitudes, personality and behaviour. Berkshire. England: Open University Press.

3. Ajzen, I., 1991. The theory of planned behaviour. Organizational Behaviour and Human Decision Processes, 50 (2), pp. 179-211.

4. Ajzen, I., 2001. Nature and operation of attitudes. Annual Review of Psychology, 52, pp. 27-58.

5. Ajzen, I., 2002. Perceived behavioural control, self-efficacy, locus of control and the theory of planned behaviour, Journal of Applied Social Psychology, 32 (4), pp. 665-683.

6. Ajzen, I. and Fishbein, M., 1980. Understanding attitudes and predicting social behaviour. Englewood Cliffs. New Jersey: Prentice-Hall.

7. Anderson, A. R., Jack, S. L., 2002. The articulation of social capital in entrepreneurial networks: A glue or a lubricant?. Entrepreneurship \& Regional Development, 14 (3), pp. 193-210.

8. Audretsch, D. B., 2007. Entrepreneurship capital and economic growth. Oxford Review of Economic Policy, 23 (1), pp. 63-78.

9. Autio, E., Keley, R. H., Klofsten, M., Parker, G. G. D., Hay, M, 2001. Entrepreneurial intent among students in Scandinavia and in the USA. Enterprise and Innovation Management Studies, 2 (2), pp. 145-160.

10. Bandura, A., 1997. Self-efficacy: The exercise of Control. New York: Worth Publishers.

11. Baron, J. N., Hannan, M. T., 1994. The Impact of Economics on Contemporary Sociology. Journal of Economic Literature, 32 (3), pp. 11111146.

12. Baron, R. A., 2004. The Cognitive perspective: A valuable tool for analysing entrepreneurship's basic "why" questions. Journal of Business Venturing, 19 (2), pp. 221-239.

13. Bernat, T., Korpysa, J., Grundey, D., Savrina, B., Bilan, Y., Koren, A., 2009. Researching Students' Entrepreneurship Skills in Post-socialist Countries: A Multi-country Survey. Transformations in Business and Economics, 8 (3), pp. 104-130.

14. Bežovan, G., Zrinščak, S., Vugec, M., 2005. Civil society in Croatia: Gaining trust and establishing partnership with the state and other stakeholders (online). Centre for Development of Non-Profit Organizations (CERANEO), CIVICUS- World Alliance for Citizen Participation. 
Management, Vol. 22, 2017, 1, pp. 1-33

K. Vuković et al.: The role of bonding and bridging cognitive social capital in shaping...

http://www.civicus.org/new/media/Croatia_country_report_English.pdf (Accessed 21 February 2013).

15. Bird, B.J., 1989. Entrepreneurial behaviour. Glenview. IL: Scott, Foresman and Company.

16. Bourdieu, P., 1986. The forms of capital. In: J. Richardson, ed. Handbook of Theory and Research for the Sociology of Education. New York: Greenwood, pp. 241-258.

17. Burt, R. S., 2001. Structural Holes versus network Closure as Social Capital. In: N. Lin, K.S. Cook and R.S. Burt, eds. Social Capital: Theory and Research, pp. 31-56.

18. Carree, M. A., Thurik, A. R., 2010. The Impact of Entrepreneurship on Economic Growth. In: Z. J. Acs. and D. B. Audretsch, eds. Handbook of Entrepreneurship Research, International Handbook Series on Entrepreneurship. New York: Springer, pp. 557-594.

19. Coleman, J, 1988. Social capital in the creation of human capital. The American Journal of Sociology, 94, pp. 95-120.

20. Cook, K., Whitmeyer, M., 1992. Two approaches to social structure: Exchange theory and network analysis. Annual Review of Sociology, 18, pp. 109-127.

21. Daut, S., 2006. Social capital in Macedonia and its impact on the economic growth (online). Center for Economic Analyses (DEA). http://www.cea. org.mk/documents/studii/Third_USAID_report_social_capita.pdf (Accessed 1 June 2014).

22. Davidsson, P., Honig, B., 2003. The role of social and human capital among nascent entrepreneurs. Journal of Business Venturing, 18, pp. 301-331.

23. de la Cruz Sánchez-Escobedo, M., Díaz-Casero, J .C., Hernández-Mogollón R., Postigo-Jiménez, M. V., 2011. Perceptions and attitudes towards entrepreneurship. An analysis of gender among university students. International Entrepreneurship and Management Journal, 7 (4), pp. 443463.

24. DePillis, E., Reardon, K. K., 2007. The influence of personality traits and persuasive messages on entrepreneurial intention. Career Development International, 12 (4), pp. 382-396.

25. Díaz-Casero, J. C., Ferreira, J. J. M., Hernández Mogollón, R., Raposo, M. L. B., 2012. Influence of institutional environment on entrepreneurial intention: a comparative study of two countries university students. International Entrepreneurship and Management Journal, 8 (1), pp. 55-74.

26. Dragojević, S., 1998. Utjecaj kulturnog, društvenog i simboličkog kapitala na razvoj zemalja Srednje i Istočne Europe. In: M. Meštrović and A. Štulhofer, eds. Sociokulturni kapital i tranzicija u Hrvatskoj. Zagreb: Hrvatsko sociološko društvo, pp. 71-86. 
27. Estrin, S., Meyer, K. E., Bytchkova, M., 2006. Entrepreneurship in transition economies. In: M. D. Casson, B. Yeung, A. Basu, and N. Wadeson, eds. The Oxford Handbook of Entrepreneurship. New York: Oxford University Press, pp. 693-725.

28. European Commission, 2010. Europe 2020, A European strategy for smart, sustainable and inclusive growth (online). Available from: http://www.socialjustice.ie/sites/default/files/file/EU/2010\%20-

\%20EU2020\%20Strategy\%20Full\%20Text.pdf(Accessed 23 March 2013).

29. European Commission, 2012. Effects and impact of entrepreneurship programmes in higher education (online). Available from: http://ec.europa.eu/enterprise/newsroom/cf/_getdocument.cfm?doc_id=742 8 (Accessed 6 June 2013).

30. European Commission, 2013. Entrepreneurship 2020 Action Plan (online). http://eur-lex.europa.eu/LexUriServ/LexUriServ.do?uri=COM:2012: 0795:FIN:EN:PDF (Accessed 8 June 2014).

31. Fornell, D., Larcker, D. F., 1981. Evaluating Structural Equation Models with Unobservable Variables and Measurement Error, Journal of Marketing Research, 18 (1), pp. 39-50.

32. Fukuyama, F., 2001. Social capital and civil society and development. Third World Quarterly, 22 (1), pp. 7-20.

33. Gefen, D., Rigdon, E. E., Straub, D., 2011. An update and extension to SEM guidelines for administrative and social science research. MIS Quarterly, 35 (2), 3-14.

34. GEM, 2014. Global Entrepreneurship Monitor 2013, Global Report, Fifteen Years of Assessing Entrepreneurship across the Globe (online). Available from: http://www.gemconsortium.org/docs/download/3106 (Accessed 12 March 2015).

35. Gird, A., Bagraim, J. J., 2008. The theory of planned behaviour as predictor of entrepreneurial intent amongst final-year university students. South African Journal of Psychology, 38 (4), pp. 711-724.

36. Gonzalez-Alvarez, N., Solis-Rodriguez, V., Guzman-Goyanes, J., 2012. Social Factors and New Venture Decisions: The Analysis Based on the Study of Cognitive Factors. Transformations in Business and Economics, 11 (1), pp. 154-166.

37. Granovetter, M., 1973. The strength of weak ties. American Journal of Sociology, 78 (6), pp. 1360-1380.

38. Granovetter, M., 1985. Economic action and social structure: the problem of embeddedness. American Journal of Sociology, 91 (3), pp. 481-510.

39. Grootaert, C., van Bastelaer, T., 2001. Understanding and measuring social capital: A synthesis of findings and recommendations from the social capital initiative, Working paper no. 24 (online). The World Bank, Social 
Management, Vol. 22, 2017, 1, pp. 1-33

K. Vuković et al.: The role of bonding and bridging cognitive social capital in shaping...

Development Department. Available from: http://siteresources.worldbank.org/INTSOCIALCAPITAL/Resources/Soci al-Capital-Initiative-Working-Paper-Series/SCI-WPS-24.pdf (Accessed 28 March 2013).

40. Haenlein, M., Kaplan, A.M. 2004. A beginner's guide to partial least squares analysis. Understanding Statistics, 3 (4), pp. 283-297.

41. Hair, J. F., Ringle, D. M., Sarstedt, M., 2011. PLS-SEM: Indeed a Silver Bullet. The Journal of Marketing Theory and Practice, 19 (2), pp. 139-151.

42. Henseler, J., Sarstedt, M., 2013. Goodness-of-fit indices for partial least squares path modelling. Comput Stat, 28, pp. 565-580.

43. Ignjatović, S., Tomanović, S., 2011. Socijalni kapital i prostor. Sociologija $i$ prostor, 49 (3), pp. 269-286.

44. Johansen, H., 2004. Ethnic dimensions of regional development in Macedonia: a research report. Eurasian Geography and Economics, 45 (7), pp. 534-544.

45. Kanas, A., van Tubergen, F., van der Lippe, T., 2009. Immigrant SelfEmployment: Testing Hypotheses About the Role of Origin- and HostCountry Human Capital and Bonding and Bridging Social Capital. Work and Occupations, 36 (3), pp. 181-208.

46. Kolvereid, I., 1996. Prediction of employment status choice intentions. Entrepreneurship Theory and Practice, 21 (1), pp. 47-57.

47. Krech, D., Crutchfield, R.S., 1969. Elementi psihologije. Beograd: Naučna knjiga.

48. Krueger, N. F., Brazeal, D. V., 1994. Entrepreneurial potential and potential entrepreneurs. Entrepreneurship Theory and Practice, 18 (3), pp. 91-104.

49. Krueger, N. F., Reilly, M. D., Darsrud, A. L., 2000. Competing models of entrepreneurial intentions. Journal of Business Venturing, 15 (5-6), pp. 411432.

50. Kuratko, D., Mathews, R. D., 2004. Community web: an internet firm's fight to survive. Entrepreneurship Theory and Practice, 28 (3), pp. 265-290.

51. Kurnoga Zivadinovic, N., 2004. Utvrđivanje osnovnih karakteristika proizvoda primjenom faktorske analize. Ekonomski pregled, 55 (11-12), pp. 853-893.

52. Leff, N. H., 1979. Entrepreneurship and economic development: The problem revisited. Journal of Economic Literature, 17 (1), pp. 46-64.

Lent, R. W., Brown, S. D., Hackett, G. (1994). Contextual supports and barriers to career choice: A social cognitive analysis. Journal of Counselling Psychology, 47, pp. 36-49.

Liñán, F., Dhen, Y. W., 2009. Development and cross-cultural application of a specific instrument to measure entrepreneurial intentions. Entrepreneurship Theory and Practice, 33 (3), pp. 593-617. 
53. Liñán, F., Santos, F. J., 2007. Does social capital affect entrepreneurial intentions?. International Advances in Economic Research, 13 (4), pp. $443-$ 453.

54. Liñán, F., Urbano, D., Guerrero, M., 2011. Regional variations in entrepreneurial cognitions: Start-up intentions of university students in Spain. Entrepreneurship \& Regional Development, 23 (3-4), p. 187-215.

55. Mihaylova, D., 2004. Social capital in Central and Eastern Europe, A critical assessment and literature review (online). Centar for Policy Studies, Central European University. http://128.118.178.162/eps/dev/papers/ 0511/0511001.pdf (Accessed 18 February 2013).

56. Mitchell, R. K., Busenitz, L., Lant, T., McDougall, P. P., Morse. E. A., Smith, J. B., 2002. Toward a theory of entrepreneurial cognition: Rethinking the people side of entrepreneurship research. Entrepreneurship Theory and Practice, 27 (2), pp. 93-104.

57. Moriano, A., Gorgievski, M., Laguna, M., Stephan, U., Zarafshani, K., 2012. A cross-cultural approach to understanding entrepreneurial intention. Journal of Career Development, 39 (2), pp. 162-185.

58. Nahapiet, J., Ghostal, S., 1998. Social capital, intellectual capital and the organizational advantage. Academy of Management Review, 23, pp. 242267.

59. Nunnally, J. D., 1975. Psychometric theory - 25 Years ago and now. Educational Researcher, 4 (10), 7-21.

60. O'Brien, D., Phillips, J. L., Patsiorskovsky, V. V., 2005. Linking indigenous bonding and bridging social capital. Regional Studies, 39 (8), pp. 1041-1051.

61. Pawlowska, A., Kacprzak, A., Strzelecki, A., 2010. To Be or Not to Be ... An Entrepreneur? The Analysis of Polish Students' Entrepreneurial Predispositions. Transformations in Business and Economics, 9 (1), pp. 124144.

62. Peng, M., Shekshnia, S. V., 2001. How entrepreneurs create wealth in transition economies. Academy of Management Executive, 15 (2), pp. 95110.

63. Portes, A., 1999. Conclusion: Towards a new world - the origins and effects of transnational activities. Ethnic and Racial Studies, 22 (2), pp. 463-477.

64. Portes, A., Landolt, P., 2000. Social capital: Promise and pitfalls of its role in development. Journal of Latin American Studies, 32 (2), pp. 529-547.

65. Pugesek, B. H., Tomer. A., von Eye, A., 2003. Structural Equation Modelling. Applications in ecological and evolutionary biology. Cambridge: Cambridge University Press.

66. Putnam, R. D., 2001. Social capital: Measurement and consequences. Isuma: Canadian Journal of Policy Research, 2 (1), pp. 41-51. 
67. Ray, J. J., 1979. Is the acquiescent response style not so mythical after all? Some results from a successful balanced F scale. Journal of Personality Assessment, 43 (6), pp. 638-643.

68. Reinartz, W., Haenleinc, M., Henseler, J., 2009. An empirical comparison of the efficacy of covariance-based and variance-based SEM. International Journal of Research in Marketing, 26, pp. 332-344.

69. Republic of Croatia, Croatian Bureau of Statistics, 2011. Stanovništvo prema starosti i spolu po naseljima, popis 2011 (online). http://www.dzs.hr/Hrv/ censuses/census2011/results/htm/H01_01_01/H01_01_01.html (Accessed 4 February 2015).

70. Republic of Macedonia, State Statistical Office, 2015. Population (online). http://www.stat.gov.mk/OblastOpsto_en.aspx?id=2, referred on 12/03/2015 (Accessed 4 February 2015).

71. Reynolds, P.D., Bygrave, W., Autio, E., Cox, L.W., and Hay, M., 2002. Global entrepreneurship monitor, 2002 Executive report (online). Kansas City, Babson College,

72. Ewing Marion Kauffman Foundation, London Business School. Available from: http://www.gemconsortium.org/docs/download/256 (Accessed 28 March 2013).

73. Ringle, D.M., Wende, S., Will, A., 2005. SmartPLS 2.0 (online). Hamburg. Available from: http://www.smartpls.de (Accessed 1 February 2013).

74. Shane, S. and Venkataraman, S., 2000. The promise of entrepreneurship as a field of research. Academy of Management Review, 25 (1),pp. 217-226.

75. Shapero, A. and Sokol, L., 1982. Social dimensions of entrepreneurship. In: D.A. Kent, D.L. Sexton, and K.H. Vesper, eds. Encyclopedia of entrepreneurship. Englewood Cliffs. NJ: Prentice-Hall, pp. 72-90.

76. Sharma, L., 2014. Impact of family capital \& social capital on youth entrepreneurship: A study of Uttarakhand state, India. Journal of Global Entrepreneurship Research, 4 (14), pp. 1-18.

77. Shook, D., Ketchen, D., Hult, G., Kacmar, K. M., 2004. An assessment of the use of structural equation models in strategic management research. Strategic Management Journal, 25 (4), pp. 397-404.

78. Štulhofer, A., Landripet, I., 2004. The dynamics of social capital in Croatia, 1995 -2003. Sociologija, 46 (3), pp. 199-210.

79. Stulhofer, A., 2004. Perception of corruption and the erosion of social capital in Croatia 1995-2003. Politička misao, 41 (5), pp. 74-86.

80. The World Bank, 2015a. GDP per capita (current US\$) (online). http://data.worldbank.org/indicator/NY.GDP.PCAP.CD (Accessed 4 February 2015). 
81. The World Bank, 2015b. Unemployment, total (\% of total labor force) (modeled ILO estimate) (online). http://data.worldbank.org/ indicator/SL.UEM.TOTL.ZS (Accessed 4 February 2015).

82. The World Bank, 2015c. Doing Business 2015, Going Beyond Efficiency, Economy Profile 2015 Croatia (online). http://www.doingbusiness.org/ data/exploreeconomies/ /media/giawb/doing\%20business/documents/profi les/country/HRV.pdf?ver=2 (Accessed 4 February 2015).

83. The World Bank, 2015d. Doing Business 2015, Going Beyond Efficiency, Economy Profile 2015 Macedonia, FYR (online). http://www.doingbusiness.org/ /media/giawb/doing\%20business/documen ts/profiles/country/MKD.pdf (Accessed 4 February 2015).

84. Tkachev, A., Kolvereid, L., 1999. Self-employment among Russian students. Entrepreneurship and Regional Development, 11 (3), pp. 269-280.

85. Tominc, P., Rebernik, M., 2007. Gender differences in early-stage entrepreneurship in three European post-socialist countries. Društvena istraživanja, 16 (3), pp.pp. 589-611.

86. Tubbs, M. E., Ekeberg, S. E., 1991. The role of intentions in work motivation: Implications for goal-setting theory and research. Academy of Management Review, 16 (1), 180-199.

87. Uphoff, N., 1999. Understanding social capital: Learning from the analysis and experiences of participation. In: I. Serageldin and P. Dasgupta, eds. Social capital: A multifaceted perspective. Washington DC: The World Bank, pp. 215-249.

88. Woolcock, M., 2004. Why and how planners should take social capital seriously? Journal of American Planning Association, 70 (2), pp. 183-189. 
Management, Vol. 22, 2017, 1, pp. 1-33

K. Vuković et al.: The role of bonding and bridging cognitive social capital in shaping...

\title{
ULOGA POVEZUJUĆEG I PREMOŠĆUJUĆEG DRUŠTVENOG KAPITALA U FORMIRANJU PODUZETNIČKE NAMJERE U TRANZICIJSKIM \\ GOSPODARSTVIMA
}

\begin{abstract}
Sažetak
Poduzetništvo je značajan čimbenik potencijalnog rasta i razvoja, koji određuje dinamiku budućeg razvoja tranzicijskih zemalja. Uzevši kao polazište teoriju planiranog ponašanja i teoriju društvenih spoznaja, u ovom se radu pretpostavlja da povezujući i premošćujući društveni kapital mogu pozitivno djelovati na poduzetničku namjeru mladih ljudi u Hrvatskoj i Makedoniji. Istraživačke hipoteze su testirane korištenjem modeliranjem strukturnih jednadžbi. Rezultati istraživanja ukazuju da povezujući i premošćujući društveni kapital mogu značajno povećati poduzetničko namjeru, pri čemu dobar indikator može biti zaključak da pojedinci s niskim povezujućim kapitalom mogu dobiti priliku na temelju premošćujućeg društvenog kapitala. Premošćujući društveni kapital, koji se stvara u poduzetničkom okruženju, može ohrabriti mlade ljude za samozapošljavanje. Nadalje, ovo istraživanje ukazuje i na nekoliko mogućih mjera unapređenja učinkovitosti poduzetničkog obrazovanja.
\end{abstract}

Ključne riječi: poduzetnička namjera, kognitivni društveni kapital, teorija planiranog ponašanja, Republika Hrvatska, FYR Makedonija 
